\title{
Synaptonemal complex behaviour in a bull homozygous for the 1;29 Robertsonian translocation
}

\author{
A Bouvet, EP Cribiu* \\ INRA, Centre de Recherche de Jouy \\ Laboratoire de Cytogénétique, 78350 Jouy-en-Josas, France
}

(Received 24 April 1990; accepted 13 June 1990)

\begin{abstract}
Summary - Analysis of synaptonemal complexes from a bull homozygous carrier for the $1 ; 29$ Robertsonian translocation showed the presence of 28 autosomal bivalent figures including one with subtelocentrically located kinetochores. No association with the sex vesicle was detected. In the $X-Y$ bivalent, a pairing segment existed between the extremity of the $X$ and $Y$ chromosomes throughout pachytene. A gap separating that complex from the rest of the $Y$ chromosome was apparent, regardless of the stain used. The results of this study confirm that there is no meiotic impairment when this homozygous translocation is present.
\end{abstract}

cattle / meiosis / synaptonemal complexes / Robertsonian translocation

Résumé - Comportement des complexes synaptonématiques chez un taureau homozygote pour la translocation robertsonienne 1;29. L'examen de complexes synaptonématiques d'un taureau homozygote pour la translocation robertsonienne 1;29 a révélé la présence de 28 bivalents autosomiques dont 1 montrant des kinétochores en position subterminale. Aucune association avec la vésicule sexuelle n'a été notée. Les extrémités des chromosomes $X$ et $Y$ sont restées appariées durant tout le stade pachytène. La séparation entre ce complexe et l'extrémité distale du chromosome $Y$ a été régulièrement notée, quel que soit le colorant employé. Les résultats de cette étude confirment que la présence de cette translocation robertsonienne à l'état homozygote n'a pas d'effet négatif sur la méiose. bovin / complexe synaptonématique / méiose / translocation robertsonienne

\section{INTRODUCTION}

The analysis of synaptonemal complexes behaviour in pachytene cells has now been incorporated into the arsenal of methods used to investigate the impact on fertility of chromosome translocations in male carriers. In humans, the negative impact of certain Robertsonian translocations on male fertility has been attributed to the association between the rearranged chromosomes and the sex vesicle (Luciani et al, 1984; Rosenmann et al, 1985). In cattle, synaptonemal complexes have also been examined in heterozygous carriers for 1;29 (Switonski et al, 1987), 4;8 (Bouvet et

\footnotetext{
* Correspondence and reprints
} 
$a l, 1989)$ and both $1 ; 29$ and 9;23 Robertsonian translocations (Bouvet and Cribiu, 1990) but no association with the sex vesicle could be noted. The present study reports the analysis of synaptonemal complex behaviour in spermatocytes from a bull homozygous carrier for the 1;29 Robertsonian translocation.

\section{MATERIALS AND METHODS}

The 1;29 Robertsonian translocation carrier examined in this study was a Blonde d'Aquitaine bull. After hemicastration of the bull, the removed testis was immersed into a container filled with HAM's F-12 culture medium, and was processed immediately for electron microscopy. The testis was cut open with a scalpel blade and a small piece of tissue was removed. Droplets of hypotonic $0.2 \mathrm{~mol} / 1$ Sucrose solution were dispersed on the surface of grease-free microscopic slides precoated with $0.5 \%$ Optilux in chloroform, and the tissue sample was lightly pressed in one swift touch on top of each droplet, to spread the spermatocytes. The slides were dried and fixed with $4 \%$ paraformaldehyde in $0.1 \mathrm{~mol} / \mathrm{l}$ sucrose. After fixation, cells were stained with either a solution of 1 part $4 \%$ phosphotungstic acid (PTA) plus 3 parts $95 \%$ ethanol or with $50 \%$ silver nitrate. After floating off the plastic film on water, 100-mesh copper grids were used to pick up selected areas. Micrographs were taken at a magnification of $3000 \times$, using a Philips CM12 transmission electron microscope at $120 \mathrm{kV}$.

In cells showing well-defined complexes, the arm ratio (long arm/short arm) was calculated for the bivalent figure showing subtelocentric kinetochores. The negatives were placed on a Biocom photometric viewing table, and the image was transmitted by a video camera (Canon macro $50 \times 3.5$ ) to a Barc monitor linked to a Compaq 386 microcomputer. All measurements were made on the screen using MIMAL image analyser software.

\section{RESULTS AND DISCUSSION}

In 17 surface-spread spermatocytes of the $1 ; 29$ homozygous translocation carrier bull, 29 bivalents could be distinguished. The 28 autosomal bivalents showed the normal structure of 2 lateral elements, one central element, densely stained kinetochores and well-defined attachment plaques. The $X-Y$ bivalent was easily identifiable by its darker staining intensity. The 28 autosomal bivalents could be classified in decreasing length, the largest bivalent figure showing a pair of well-aligned subtelocentric kinetochores, whereas the others showed terminal kinetochores (fig 1). By the end of pachytene, all autosomal complexes showed complete synapsis. In the 17 cells examined, the average arm ratio for the $1 ; 29$ bivalent was $3.06 \pm 0.86$. This agrees only partially with the corresponding index of 3.01-3.38 of the mitotic $1 ; 29$ translocation chromosome (Gustavsson, 1969; Popescu, 1971). The 1;29 bivalent figure remained independant from the sex vesicle in all cells examined. The $X-Y$ bivalent showed a pairing segment at the extremity of the $X$ chromosome throughout pachytene and an unstained gap between that segment and the terminal part of the $Y$ chromosome was generally noted (fig 2). All these features were noted in cells stained with either PTA or with silver nitrate. 

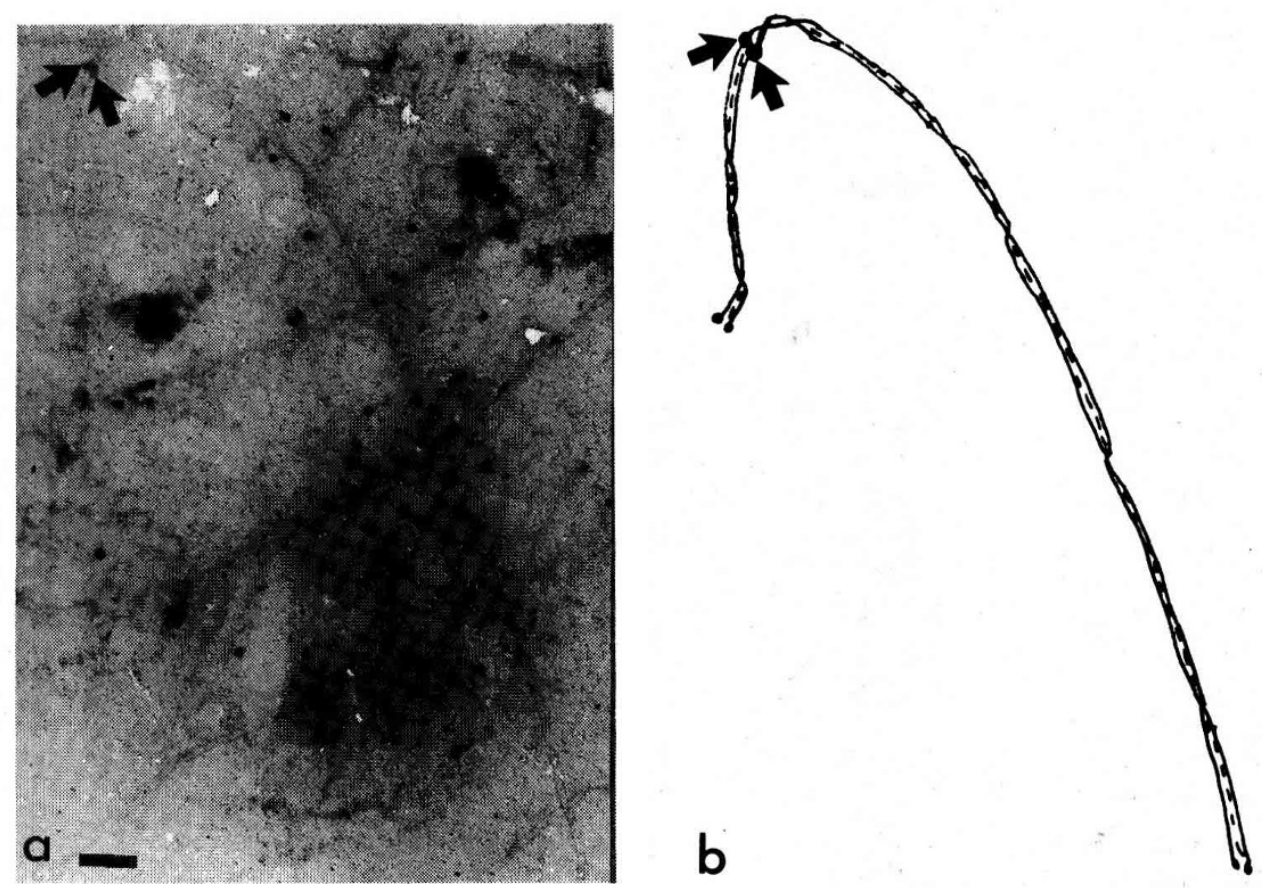

Fig 1. Electron micrograph $(a)$ and tracing $(b)$ of a partial spermatocyte spread showing a completely paired bivalent figure with 2 well-defined kinetochores in a subtelocentric position (arrowheads), whereas the other autosomal bivalents showed terminally located kinetochores (silver nitrate). Bar $=1 \mu \mathrm{m}$.

Complete pairing of autosomal axes by the end of pachytene, absence of association with the sex vesicle and the presence of an $X Y$ pairing segment at one extremity of the $X$ chromosome throughout pachytene, were similar to the features already noted in normal and heterozygous bulls (Switonski and Gustavsson, 1986; Switonski et al, 1987; Bouvet et al, 1989; Dollin et al, 1989; Bouvet and Cribiu, 1990).

The separation between the $X-Y$ synaptonemal complex and the distal part of the $Y$ chromosome had already been reported in PTA stained material (Switonski and Gustavsson, 1986; Bouvet et al, 1989). The results of the present study and that of Dollin et al (1989), using silver nitrate and PTA clearly showed that it is a constant feature of $X-Y$ bivalents, regardless of the stain used. Whether this gap is an unstained segment of the $Y$ chromosome, due to a different molecular organization resulting in a low staining ability (Bouvet et al, 1989) or whether it is the result of the mechanical separation of the free end of the $Y$ chromosome from the $X-Y$ synaptonemal complex at the extremity of the $X$ chromosome, during the hypotonic shock (Dollin et al, 1989) still remains to be established. 


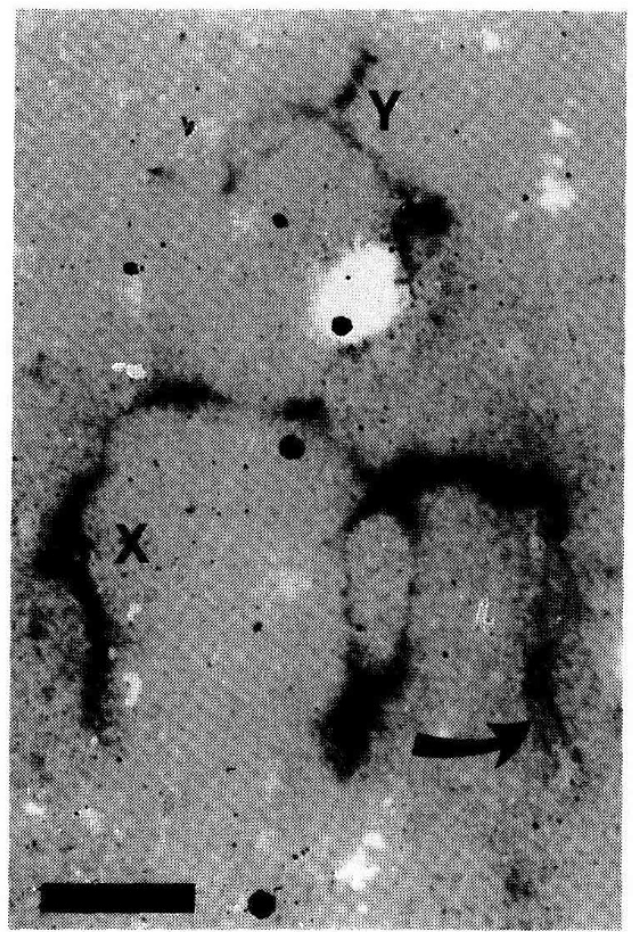

Fig 2. $X-Y$ bivalent showing the pairing segment between the $X$ and $Y$ chromosomes (arrow), at one extremity of the $X$ chromosome, and the remaining part of the $Y$ chromosome separated by an unstained gap (silver nitrate). Bar $=1 \mu \mathrm{m}$.

\section{ACKNOWLEDGMENTS}

The authors wish to thank J Fléchon, M Rousseau and their laboratory staff (CRJINRA, 78350 Jouy-en-Josas) for their efficient technical help in various aspects of the electron microscopic procedures. Analysis of the micrographs would not have been possible without the collaboration of $\mathrm{Dr} J$ Serviere and Mrs G Gendrot (laboratoire de physiologie sensorielle, CRJ), who graciously agreed to let us use their Biocom Image Analyzer apparatus. Thanks are also extended to Mr G Fabre and his technical staff at the Carmeaux field station for their invaluable help in the housing and caring of the animal and their assistance during the surgical procedure.

\section{REFERENCES}

Bouvet A, Cribiu EP (1990) Analysis of synaptonemal complexes behaviour in a subfertile bull carrying 1;29 and 9;23 Robertsonian translocations. Zuchthygiene (submitted) 
Bouvet A, Popescu CP, De Giovanni-Macchi A, Colombo G, Molteni L (1989) Synaptonemal complexes analysis in a bull carrying a 4;8 Robertsonian translocation. Ann Génét 32, 193-199

Dollin A, Murray JD, Gillies CB (1989) Synaptonemal complex analysis of hybrid cattle. I Pachytene substaging and the normal full bloods. Genome 32, 856-864

Gustavsson I (1969) Cytogenetic, distribution and phenotypic effects of a translocation in Swedish cattle. Hereditas 63, 68-169

Luciani JM, Guichaoua MR, Mattei A, Morrazzani MR (1984) Pachytene analysis of a man with a 13;14 translocation and infertility. Behavior of the trivalent and nonrandom association with the sex vesicle. Cytogenet Cell Genet 38, 14-22

Popescu CP (1971) Deux cas nouveaux de fusion centrique chez les bovins. Ann Génét Sél Anim 3, 521-525

Rosenmann A, Wahrman J, Richler C, Voss R, Persitz A, Goldman B (1985) Meiotic association between the $X Y$-chromosomes and unpaired autosomal elements as a cause of human sterility. Cytogenet Cell Genet 39, 19-29

Switonski M, Gustavsson I (1986) The synaptonemal complex of the $X-Y$ bivalent in pigs and cattle studied by electron microscopy. Proc 7th Eur Colloq Cytogenet Dom Anim, Warsaw, Poland

Switonski M, Gustavsson I, Plöen L (1987) The nature of the 1;29 translocation in cattle as revealed by synaptonemal complex analysis using electron microscopy. Cytogenet Cell Genet 44, 103-111 